\title{
Influence of energy supply on microbial protein synthesis and renal urea handling in Corriedale sheep*
}

\author{
I. Tebot ${ }^{1}$, A.L. Ibarra, F. Purtscher and A. Cirio \\ Departamento de Fisiología, Facultad de Veterinaria \\ Montevideo 11600, Uruguay
}

\begin{abstract}
The effect of high energy intake on microbial protein production and renal urea kinetics was studied in Corriedale sheep by the urinary allantoin method and renal functional tests. High energy diet increased microbial protein production $(6.61 \pm 0.90$ vs $4.30 \pm 0.60 \mathrm{~g} / \mathrm{d}$ in normal energy diet, $\mathrm{P}<0.05)$. The efficiency of $\mathrm{N}$ utilization by rumen microbes tended to improve $(19.8 \pm 4.2 \mathrm{vs}$ $16.8 \pm 1.9 \mathrm{~g}$ microbial N/kg DOMR, NS). A reduction in fractional excretion of urea and a tendency to decrease of urinary urea elimination were also observed. This renal urea sparing reduced $\mathrm{N}$ losses, contributing to the blood urea pool available for rumen recycling.
\end{abstract}

KEY WORDS: energy supply, microbial protein synthesis, urea, kidney, sheep

\section{INTRODUCTION}

Ruminants are able to use endogenous urea $\mathrm{N}$ to synthesise microbial proteins in their forestomachs. When the urea recycled into rumen matches with an adequate energy supply, microbial cell yields is enhanced and the flow of microbial protein to the small intestine increased (Obara et al., 1991). Owing to the characteristics of breeding and feeding in Uruguay, Corriedale sheep graze different kinds of pastures with a high level of $\mathrm{N}$ content throughout the year. This higher $\mathrm{N}$ intake is not always associated with the necessary energy supply that improves its microbial utilization, giving rise to a loss of the excessive $\mathrm{N}$ as urinary urea and ammonia. The use of an additional source of energy has been proposed as a procedure to improve the microbial capture of ammonia-N and consequently enhance the nitrogen retention and the microbial protein production (Jetana et al., 2000). The aim of this work was to evaluate the effect of supplementation with a

\footnotetext{
${ }^{*}$ Supported by Facultad de Veterinaria, Universidad de la República, Uruguay

${ }^{1}$ Corresponding author: e-mail: itebot@montevideo.com.uy
} 
rapidly fermentable energy source on the efficiency of microbial protein synthesis and on renal urea handling.

\section{MATERIAL AND METHODS}

Six non-pregnant non lactating caged Corriedale ewes were fed three times a day with, successively, a normal (NE, maintenance) and a high (HE, 30\% additional energy as entire grain maize) energy rations. For detailed composition, intake and digestibility of the diets see Table 1. Glomerular filtration rate and clearance, filtered load and fractional excretion of urea were determined using standard clearance methods. Allantoin was analysed in urine by the method of Young and Conway, modified by Fujihara (1987). Microbial protein synthesis was estimated according to the equation:

$$
y=e^{(0.830+2.089 x)}
$$

proposed by Puchala and Kulasek (1992), where $y=$ microbial $\mathrm{N}$ entering the duodenum and $x=$ urinary excretion of allantoin $\mathrm{N}$. The efficiency of the microbial protein synthesis in the rumen was calculated as $g$ of microbial $\mathrm{N}$ per $\mathrm{kg}$ of digestible organic matter apparently digested in rumen (DOMR). Statistical significances were evaluated by a Student paired $t$-test.

Table 1. Composition, intake and digestibility of normal (NE) and high energy (HE) diets on the basis of 40-kg liveweight (DOMI: digestible organic matter intake)

\begin{tabular}{lcc}
\hline & NE & HE \\
\hline Diet contents, g/d & & \\
dehydrated lucerne pellets & 330 & 200 \\
entire maize grain & 200 & 450 \\
grass hay (Stipa spp.) & 270 & 150 \\
Daily intake, g/d & & \\
diet as fed & 800 & 800 \\
dry matter & 708 & 712 \\
organic matter & 662 & 680 \\
nitrogen & 15 & 13 \\
energy, Mcal & 1.72 & 2.23 \\
& & \\
Digestibility & & $524 \pm 0.04$ \\
DOMI, g & $425 \pm 0.10$ & \\
\hline
\end{tabular}

\section{RESULTS}

Results are summarized on Table 2. 
Table 2. Changes in microbial protein synthesis, plasma urea level and renal urea handling in sheep under normal (NE) and high (HE) energy diets

\begin{tabular}{lcc}
\hline Parameters & $\mathrm{NE}$ & $\mathrm{HE}$ \\
\hline Urine allantoin excretion, mmol/d/kg BW ${ }^{0.75}$ & $0.33 \pm 0.08$ & $0.63 \pm 0.07^{*}$ \\
Microbial protein production, microbial N/g/d & $4.30 \pm 0.60$ & $6.61 \pm 0.9^{*}$ \\
Efficiency of microbial protein production, & & \\
$\quad$ g microbial N/kg DOMR & $16.8 \pm 1.9$ & $19.8 \pm 4.2$ \\
Plasma urea, $\mathrm{mg} / \mathrm{ml}$ & $0.25 \pm 0.10$ & $0.19 \pm 0.05^{*}$ \\
Glomerular filtration rate, $\mathrm{ml} / \mathrm{min}$ & $111.38 \pm 27.30$ & $134.52 \pm 25.14$ \\
Urea clearance, $\mathrm{ml} / \mathrm{min}$ & $61.12 \pm 22.68$ & $43.78 \pm 6.63$ \\
Filtered load of urea, $\mathrm{mg} / \mathrm{min}$ & $26.75 \pm 5.51$ & $26.83 \pm 10.32$ \\
Urea eliminated, $\mathrm{mg} / \mathrm{min}$ & $13.97 \pm 1.77$ & $8.84 \pm 4.01$ \\
Fractional excretion of urea & $0.57 \pm 0.14$ & $0.32 \pm 0.05^{*}$ \\
\hline
\end{tabular}

values $=$ means $\pm \mathrm{SD}, \mathrm{n}=6, * \mathrm{P}<0.05$

\section{DISCUSSION}

The increased urinary allantoin elimination induced by the high energy diet disclosed an enhanced microbial protein synthesis in the forestomachs. On this diet, we found a tendency to a higher efficiency in $\mathrm{N}$ utilization in the rumen similar to that reported by Jetana et al. (2000) in Merino rams supplemented with maize flour. In our experimental conditions, the $30 \%$ energy supplementation was without negative effects on the intake of the basal diet (substitution effect) or the digestibility.

At the kidney level, the decreased fractional excretion of urea and the tendency to less urea elimination indicated a renal $\mathrm{N}$ retention in HE group at the tubular level. This renal sparing mechanism differs from that previously reported in low protein fed Corriedale sheep (Tebot et al., 2002) in the absence of changes in glomerular filtration rate. The results suggested a contribution of kidneys to the blood urea pool increasing its availability for ruminal recycling. The fact that blood urea was found lowered under HE diet could be explained by higher transfers of urea to digestive tract as reported by Obara et al. (1991).

\section{CONCLUSIONS}

In Corriedale ewes, the supplementation of the basal diet with a high energy source enhanced the protein synthesis in the forestomachs and tended to improve the efficiency in the $\mathrm{N}$ utilization by ruminal microbes. The renal urea sparing observed on this conditions reduced the $\mathrm{N}$ losses, thereby contributing to the blood urea pool. 


\section{REFERENCES}

Fujihara T., Ørskov E.R., Reeds P.J., Kyle D.J., 1987. The effect of protein infusion on urinary excretion of purine derivatives in ruminants nourished by intragastric nutrition. J. Agr. Sci. 109, $7-12$

Jetana T., Abdullah N., Halim R.A., Jalaludin S., Ho Y.W., 2000. Effects of energy and protein supplementation on microbial-N synthesis and allantoin excretion in sheep fed guinea grass. Anim. Feed Sci. Tech. 84, 167-181

Obara Y., Dellow D.W., Nolan J.V., 1991. The influence of energy-rich supplements on nitrogen kinetics in ruminants. In: T. Tsuda, Y. Sasaki, R. Kawashima (Editors). Physiological Aspects of Digestion and Metabolism in Ruminants. Proceedings of the $7^{\text {th }}$ International Symposium on Ruminant Physiology, pp. 515-539

Puchala R., Kulasek G.W., 1992. Estimation of microbial protein flow from the rumen of sheep using microbial nucleic acid and urinary excretion of purine derivatives. Can. J. Anim. Sci. 72, $821-830$

Tebot I., Britos A., Godeau J.M., Cirio A., 2002. Microbial protein production determined by urinary allantoin and renal urea sparing in normal and low protein fed Corriedale sheep. Vet. Res. 33, 101-106 